\title{
Digestible energy of crude glycerol for pacu and silver catfish
}

\author{
Energia digestível do glicerol bruto para o pacu e o jundiá \\ Rafael Ernesto Balen ${ }^{I^{*}}$ Patrick Nereu Tetu ${ }^{\mathrm{II}}$ Robie Allan Bombardelli ${ }^{\mathrm{II}}$ \\ Paulo Cesar Pozza ${ }^{\text {IV }}$ Fábio Meurer ${ }^{\mathrm{I}, \mathrm{III}}$
}

- NOTE -

\begin{abstract}
The increase in global biodiesel production is originating a glycerol surplus, which has no defined destination. An alternative to overcome this problem is its use as energy source in animal feeding. In Brazil, Pacu (Piaractus mesopotamicus) is one of the most farmed native fish species, whereas Silver catfish (Rhamdia quelen) is suitable for production in subtropical region. Considering little knowledge about crude glycerol utilization in feeds for Neotropical fish species, it was evaluated the apparent digestibility coefficients (ADCs) for energy of crude glycerol for P. mesopotamicus and $\boldsymbol{R}$. quelen. The digestibility and digestible energy content of crude glycerol can be considered excellent even when compared to energy of common ingredients such as maize and wheat, presenting 0.97 and 0.89 of energy ADCs, and 15.2 and $13.95 \mathrm{MJ} \mathrm{kg}^{-1}$ of digestible energy for Pacu and Silver catfish, respectively. In conclusion, crude glycerol is an energetic ingredient with good potential in Brazilian native fish diets.
\end{abstract}

Key words: byproduct, glycerin, non-protein energy, nutrition.

\section{RESUMO}

O aumento na produção mundial de biodiesel está gerando um excesso de glicerol, sem destinação definida. Uma alternativa para superar este problema é seu uso como fonte de energia na alimentação animal. No Brasil, o pacu (Piaractus mesopotamicus) é uma das espécies de peixes nativas mais cultivadas, enquanto que o jundiá (Rhamdia quelen) é apropriado para a produção na região subtropical. Considerando a falta de conhecimento sobre a utilização do glicerol bruto em rações para espécies de peixes Neotropicais, determinaram-se os coeficientes de digestibilidade aparente (CDAs) para a energia do glicerol bruto em P. mesopotamicus e R. quelen. A digestibilidade e o conteúdo de energia digestível do glicerol bruto podem ser considerados excelentes, mesmo quando comparados à energia de ingredientes comuns, como o milho e o trigo, apresentando para energia CDA de 0,97 e 0,89, e 15,2 e 13,95 $\mathrm{MJ} \mathrm{kg}^{-1}$ de energia digestível para o pacu e o jundiá, respectivamente. Por fim, o glicerol bruto é um ingrediente energético com bom potencial para dietas de peixes nativos do Brasil.

Palavras-chave: subproduto, glicerina, energia não-proteica, nutrição.

South America has the richest ichthyofauna of all continents (SAINT-PAUL, 1986). Among these species, the Pacu Piaractus mesopotamicus (Holmberg) stands out for its easy adaptation to be farmed and to consume a diverse number of feedstuffs (ABIMORAD \& CARNEIRO, 2004). On the other hand, Silver catfish Rhamdia quelen (Quoy \& Gaimard) is an omnivorous fish with interest for aquaculture in Brazil, Argentina, and Uruguay (SALHI \& BESSONART, 2012), because it withstands cold winters and presents fast growth rate in summer, characteristics that make it a suitable species for fish production in southern South America (PEREIRA et al., 2006).

Glycerol is the main byproduct generated in biodiesel production (DASARI et al., 2005), an alternative fuel obtained from renewable lipids such as those in vegetable oils or animal fat (LUCENA et al., 2008). It is estimated that by 2016 the world biodiesel market will achieve the quantity of 37 billion gallons, which means that more than 4 billion gallons of crude glycerol will be produced every year (KOŚMIDER et

\footnotetext{
'Programa de Pós-graduação em Zoologia, Departamento de Zoologia, Universidade Federal do Paraná (UFPR), CP 19020, 81531-980, Curitiba, PR, Brasil. E-mail: rebalen@yahoo.com.br. *Autor para correspondência.

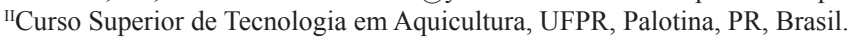

IIIPrograma de Pós-graduação em Aquicultura e Desenvolvimento Sustentável, UFPR, Palotina, PR, Brasil.

IV Departamento de Zootecnia, Universidade Estadual de Maringá (UEM), Maringá, PR, Brasil. 
al., 2011). Such glycerol surplus will not only result in a further reduction in prices, but the disposal of these streams will become a major issue (MCCOY, 2006).

The development of new markets to absorb the crude glycerol production can reduce its accumulation, as well as establish a sustainable industrial chain for biofuels. Crude glycerol utilization in fish diets was reported only to Channel catfish (LI et al., 2010) and Nile tilapia (NEU et al., 2012a, 2013). There are no studies on the digestible energy of glycerol in Neotropical fish species, and little information published is restricted to Nile tilapia (MEURER et al., 2012; NEU et al., 2012b). The present study aimed to determine the apparent digestibility coefficients (ADCs) of crude glycerol energy for P. mesopotamicus and $\boldsymbol{R}$. quelen.

The experiment was performed at Aquatic Organisms Nutrition Laboratory of Universidade Federal do Paraná, Setor Palotina, Paraná State, Brazil. Crude glycerol was provided by BSBIOS Indústria e Comércio de Biodiesel Sul Brasil S/A, Passo Fundo, Rio Grande do Sul State, Brazil. Due to its high hygroscopic degree, crude glycerol was dried in a ventilated drying oven at $55^{\circ} \mathrm{C}$ for $24 \mathrm{~h}$ before ration manufacture. ADCs for energy were measured indirectly using $0.1 \%$ of chromic oxide $\left(\mathrm{Cr}_{2} \mathrm{O}_{3}\right)$ as an inert marker. The reference and test diets were formulated and pelletized based on vegetable food (Table 1).

The fish were housed in one cage (100L) per species. For each species, a polyethylene circular tank $(1,000 \mathrm{~L})$ was utilized as feeding tank and a cylinder-conical tank (150L) as a faecal collecting tank. Feeding and feces collection tanks were aerated

Table 1 - Composition of experimental feeds $\left(\mathrm{g} \mathrm{kg}^{-1}\right)$.

\begin{tabular}{lcl}
\hline Ingredient & Reference diet & Test diet \\
\hline Soybean meal & 661.6 & 463.1 \\
Maize & 290.7 & 203.5 \\
Soybean oil & 11.1 & 7.8 \\
Dicalcic phosphate & 18.4 & 18.4 \\
Calcitic lime & 2.2 & 2.2 \\
Mineral and vitamin & 10.0 & 10.0 \\
supplement & & \\
Salt & 5.0 & 5.0 \\
$\mathrm{Cr}_{2} \mathrm{O}_{3}$ & 1.0 & 1.0 \\
$\mathrm{Glycerol}$ & - & 289.0 \\
\hline
\end{tabular}

${ }^{1}$ Warranty levels per product kilogram: Vit. A, 1,200,000UI, Vit. D3, 200,000UI, Vit. E, 12,000mg, Vit. K3, 2,400mg, Vit. B1, $4,800 \mathrm{mg}$, Vit. B2, 4,800mg, Vit. B6, 4,000mg, Vit. B12, 4,800mg, Folic acid, 1,200mg, Pantotenate Ca, 12,000mg, Vit. C, $48,000 \mathrm{mg}$, Biotin, $48 \mathrm{mg}$, Coline, $65,000 \mathrm{mg}$, Niacin, $24,000 \mathrm{mg}$, $\mathrm{Fe}, 10,000 \mathrm{mg}, \mathrm{Cu}, 6,000 \mathrm{mg}, \mathrm{Mn}, 4,000 \mathrm{mg}, \mathrm{Zn}, 6,000 \mathrm{mg}, \mathrm{I}$, $20 \mathrm{mg}, \mathrm{Co}, 2 \mathrm{mg}$, Se, 20mg. continuously $\left(>5 \mathrm{mg} \mathrm{L}^{-1}\right)$ and temperature was maintained by thermostatic heaters at $28 \pm 1.5^{\circ} \mathrm{C}$.

Fish juveniles (Pacu, 129.06 $\pm 29.27 \mathrm{~g}$, $18.46 \pm 1.52 \mathrm{~cm}, \mathrm{n}=25$; Silver catfish, $69.06 \pm 12.77 \mathrm{~g}$, $19.79 \pm 1.14 \mathrm{~cm}, \mathrm{n}=30$ ) were submitted to an adaptation period ( 5 days) to the experimental conditions and diets. Thereafter, fish were kept in cages at feeding tanks from 07:30 to 18:00h, fed once in the morning (at 11:00 hours) and from 16:30 to 17:40h, until apparent satiation. After 20min of last feeding, the fish were transferred to cylinder-conical tanks, where they remained until 07:30h of the following morning, when these came back again to feeding tanks. The techniques used for the faecal collection and processing were the same as adapted by Meurer et al. (2012).

Gross energy content was measured by combustion in an adiabatic bomb calorimeter (Parr Instruments, Moline, IL, USA, model Parr 6200), and chromic oxide was determined using a process involving perchloric and nitric acid digestion followed by atomic absorption spectrometric determination (KIMURA \& MILLER, 1957). The crude glycerol energy ADCs values were calculated according to NRC (2011).

Crude glycerol presented $15.67 \mathrm{MJ} \mathrm{kg}^{-1}$ of gross energy, $93.24 \%$ of dry matter, and $6.06 \%$ of ash. Energy ADCs were 0.97 and 0.89 , and digestible energy were 15.2 and $13.95 \mathrm{MJ} \mathrm{kg}^{-1}$, for Pacu and Silver catfish, respectively.

ADCs results and digestible energy content to crude glycerol determined in this study were higher than those described to Nile tilapia by MEURER et al. (2012) (0.89 and 13.09MJ kg-1) and NEU et al. (2012b) (0.81 and $10.91 \mathrm{MJ} \mathrm{kg}^{-1}$ to semi-purified mixture glycerol, 0.58 and $12.78 \mathrm{MJ} \mathrm{kg}^{-1}$ to crude vegetable oil glycerol, and 0.47 and $7.33 \mathrm{MJ} \mathrm{kg}^{-1}$ to semi-purified vegetable glycerol, respectively).

Compared to the ADCs and digestible energy values from other energy ingredients for Pacu, glycerol was higher than wheat meal $(0.81$ and $13.84 \mathrm{MJ} \mathrm{kg}^{-1}$, respectively), maize $(0.87$ and $14.48 \mathrm{MJ}$ $\left.\mathrm{kg}^{-1}\right)$, and sorghum $\left(0.93\right.$ and $\left.14.51 \mathrm{MJ} \mathrm{kg}^{-1}\right)$, and lower than rice meal ( 0.93 and $\left.17.60 \mathrm{MJ} \mathrm{kg}^{-1}\right)$ (ABIMORAD \& CARNEIRO, 2004). FERNANDES et al. (2004) observed lower values for digestible energy in maize (14.02MJ kg-1) and wheat bran (7.46MJ kg-1) for Piaractus brachypomus (Cuvier).

When it comes to Silver catfish, these values were higher than those reported by OLIVEIRA FILHO \& FRACALOSSI (2006) for maize (0.59 and 9.62MJ kg-1) and broken rice $\left(0.64\right.$ and $\left.10.28 \mathrm{MJ} \mathrm{kg}^{-1}\right)$. Regarding another Neotropical catfish species, TEIXEIRA et al. (2010) described ADCs values of gross energy for maize $(0.62)$, rice bran $(0.66)$, broken rice $(0.46)$, and 
sorghum (0.47) for sorubim (Pseudoplatystoma sp.). Moreover, GONÇALVES \& CARNEIRO (2003) observed values of 0.64 for maize, 0.48 for sorghum, 0.51 for rice bran, and 0.47 for broken rice in spotted sorubim P. corruscans (Spix \& Agassiz) diets, and SILVA et al. (2013) reported for striped sorubim (P. reticulatum Eigenmann \& Eigenmann) ADC values of 0.43 for maize.

All these values were lower than those of gross energy ADCs of crude glycerol determined in this study for silver catfish, probably due to their different chemical compositions. The above mentioned ingredients have a lot of starch in its composition, which is not well utilized by fish, especially carnivorous species, characteristic related to the utilization of carbohydrates (SHIAU, 1997) or glucose intolerance (MOON, 2001) in fish.

The good energy digestibility determined for glycerol as well as the amount of digestible energy can be related to the ease in which this nutrient is digested, absorbed and used by both species. According to LIN (1977), glycerol is absorbed in the intestine, enters into the bloodstream and subsequently is used by liver and tissues for glucose synthesis by gluconeogenesis or energy production by glycolysis and citric acid cycle.

These results show the possibility of crude glycerol to be used as energy source in Pacu and Silver catfish diets. The current increase in biofuel production originates a large surplus of crude glycerol and its use in feed formulation could reduce costs and improve profits of both productive chains. Therefore, additional experiments must be performed to evaluate crude glycerol replacing other energy sources in fish diets, to evaluate its productive performance, feed efficiency and body composition in different phases of growth.

Crude glycerol derived from the biodiesel production is an energy source with good potential for omnivorous fish species, presenting ADC of 0.97 and 0.89 , and digestible energy content of 15.2 and $13.95 \mathrm{MJ}$ $\mathrm{kg}^{-1}$ as fed basis for Pacu and Silver catfish, respectively.

\section{ACKNOWLEDGMENTS}

Rafael Ernesto Balen received a fellowship from Conselho Nacional de Desenvolvimento Científico e Tecnológico (CNPq), grant n.140202/2012-9.

\section{ETHICS COMITTE AND BIOSECURITY}

This study was approved by Ethical Committee on Animal Experimentation of the Universidade Federal do Paraná (Protocol n.14/2011 - CEUA Campus Palotina).

\section{REFERENCES}

ABIMORAD, E.; CARNEIRO, D.J. Fecal collection methods and determination of crude protein and of gross energy digestibility coefficients of feedstuffs for pacu, Piaractus mesopotamicus (HOLMBERG, 1887). Revista Brasileira de Zootecnia, v.33 n.5, p.1101-1109, 2004. Available from: <http://www.scielo.br/ pdf/rbz/v33n5/a01v33n5.pdf $>$. Accessed: May 22, 2013. doi: 10.1590/S1516-35982004000500001.

DASARI, M.A. et al. Low-pressure hydrogenolysis of glycerol to propylene glycol. Applied Catalysis A: General, v.281, n.12, p.225-231, 2005. Available from: <http://ac.els-cdn.com/ S0926860X0400941X/1-s2.0-S0926860X0400941X-main.pdf? tid $=5$ f884c26-a0ac-11e3-a4b3-00000aacb360\&acdnat $=1393614975_{-}$ c5190babbe0622f9397647a0003124ae>. Accessed: Oct. 11, 2011. doi: 10.1016/j.apcata.2004.11.033.

FERNANDES, J.B.K. et al. Apparent digestible energy and nutrient digestibility coefficients of diet ingredients for pacu Piaractus brachypomus. Journal of the World Aquaculture Society, v.35, n.2, p.237-244, 2004. Available from: <http://onlinelibrary.wiley. com/doi/10.1111/j.1749-7345.2004.tb01080.x/pdf >. Accessed: May 22, 2013. doi: 10.1111/j.1749-7345.2004.tb01080.x.

GONÇALVES, E.G.; CARNEIRO, D.J. Coeficientes de digestibilidade aparente da proteína e energia de alguns ingredientes utilizados em dietas para o pintado (Pseudoplatystoma coruscans). Revista Brasileira de Zootecnia, v.32, n.4, p.779786, 2003. Available from: <http://www.scielo.br/pdf/rbz/ v32n4/17853.pdf $>$. Accessed: Apr. 16, 2013. doi: 10.1590/S151635982003000400001 .

KIMURA, F.T.; MILLER, V.L. Improved determination of chromic oxide in cow feed and feces. Journal of Agricultural Foodstuffs Chemistry, v.5, p.216, 1957.

KOŚMIDER, A. et al. Improved utilization of crude glycerol by-product from biodiesel production. In: MONTERO, G. (Ed.). Biodiesel - Quality, emissions and by-products. Rijeka: InTech, 2011. p.341-364. Available from: <http://www.intechopen.com/ books/biodiesel-quality-emissions-and-by-products/improvedutilization-of-crude-glycerol-by-product-from-biodieselproduction>. Accessed: Nov. 25, 2012.

LI, M.H. et al. Evaluation of glycerol from biodiesel production as a feed ingredient for channel catfish, Ictalurus punctatus. Journal of the World Aquaculture Society, v.41, n.1, p.130136, 2010. Available from: <http://onlinelibrary.wiley.com/ doi/10.1111/j.1749-7345.2009.00320.x/pdf>. Accessed: Apr. 16, 2013. doi: $10.1111 / \mathrm{j} .1749-7345.2009 .00320 . x$.

LIN, E.C.C. Glycerol utilization and its regulation in mammals. Annual Review of Biochemistry, v.46, p.765-795, 1977. Available from: <http:/www.annualreviews.org/doi/pdf/10.1146/ annurev.bi.46.070177.004001>. Accessed: Sept. 29, 2012. doi: 10.1146/annurev.bi.46.070177.004001

LUCENA, I.L. et al. Biodiesel production by esterification of oleic acid with methanol using a water adsorption apparatus. Industrial \& Engineering Chemistry Research, v.47, n.18, p.6885-6889, 2008. Available from: <http://pubs.acs.org/doi/pdf/10.1021/ie800547h>. Accessed: Oct. 11, 2011. doi: 10.1021/ie800547h.

MCCOY, M. Glycerin surplus. Chemical \& Engineering News, v.84, n.6, p.7, 2006. Available from: <http://pubs.acs.org/doi/ 
pdf/10.1021/cen-v084n006.p007a>. Accessed: Oct. 11, 2011. doi: 10.1021/cen-v084n006.p007a.

MEURER, F. et al. Apparent energy digestibility of glycerol from biodiesel production for Nile tilapia (Oreochromis niloticus, Linnaeus 1758). Aquaculture Research, v.43, n.11, p.17341737, 2012. Available from: <http://onlinelibrary.wiley.com/ doi/10.1111/j.1365-2109.2011.02974.x/pdf>. Accessed: Jan. 30, 2013. doi: 10.1111/j.1365-2109.2011.02974.x.

MOON, T.W. Glucose intolerance in teleost fish: fact or fiction? Comparative Biochemistry and Physiology B, v.129, n.23, p.243-249, 2001. Available from: <http://ac.els-cdn.com/ S1096495901003165/1-s2.0-S1096495901003165-main.pdf? tid=e1ebb598-a207-11e3-8889-00000aab0f27\&acdnat=1393764229 f17293b4279a9a45aefbefc0883fc0f6>. Accessed: Jun. 23, 2011. doi: $10.1016 /$ S1096-4959(01)00316-5.

NATIONAL RESEARCH COUNCIL (NRC). Nutrient requirements of fish and shrimp. Washington: The National Academies, 2011. Chapt.12, p.253-271.

NEU, D.H. et al. Glicerol na dieta de alevinos de tilápia do Nilo (Oreochromis niloticus). Revista Agrarian, v.5, n.17, p.288-294, 2012a. Available from: $<$ http://www.periodicos.ufgd.edu.br/index. php/agrarian/article/view/1701/1101>. Accessed: Jan. 30, 2013.

NEU, D.H. et al. Energia digestível de diferentes fontes de glicerol para a tilápia-do-Nilo (Oreochromis niloticus). Revista Brasileira de Ciências Agrárias, v.7, n.1, p.174-179, 2012b. Available from: <http://www.agraria.pro.br/sistema/index.php? journal $=$ agraria $\&$ page $=$ article $\&$ op $=$ view $\&$ path $\% 5 \mathrm{~B} \% 5 \mathrm{D}=$ agrar ia_v7i1a1501\&path\%5B\%5D=1091>. Accessed: Jan. 30, 2013. doi: 10.5039 /agraria.v7i1a1501.

NEU, D.H. et al. Glycerol inclusion in the diet of Nile tilapia (Oreochromis niloticus) juveniles. Aquaculture Nutrition, v.19, n.2, p.211-217, 2013. Available from: <http://onlinelibrary.wiley. com/doi/10.1111/j.1365-2095.2012.00968.x/pdf>. Accessed: June 18, 2013. doi: 10.1111/j.1365-2095.2012.00968.x.

OLIVEIRA FILHO, P.R.C.; FRACALOSSI, D.M. Coeficientes de digestibilidade aparente de ingredientes para juvenis de jundiá. Revista Brasileira de Zootecnia, v.35, n.4, p.1581-1587, 2006. Available from: <http://www.scielo.br/pdf/rbz/v35n4s0/ a02v354s.pdf $>$. Accessed: Mar. 12, 2012. doi: 10.1590/S151635982006000600002 .

PEREIRA, C.R. et al. Embryonic and larval development of jundiá (Rhamdia quelen, Quoy \& Gaimard, 1824, Pisces, Teleostei), a South American catfish. Brazilian Journal of Biology, v.66, n.4, p.1057-1063, 2006. Available from: <http:/www.scielo.br/ pdf/bjb/v66n4/12.pdf>. Accessed: Mar. 12, 2012. doi: 10.1590/ S1519-69842006000600013.

SAINT-PAUL, U. Potential for aquaculture of South American freshwater fishes: a review. Aquaculture, v.54, n.3, p.205-240, 1986. Available from: <http://ac.els-cdn. com/0044848686903297/1-s2.0-0044848686903297-main.pdf? tid $=0420791$ e-a208-11e3-a4fe-00000aacb360\&acdnat $=1393764 \overline{2}$ 86 7b705ca7330c0c81c30625a5f9b37a7b>. Accessed: Mar. 12, 2012. doi: 10.1016/0044-8486(86)90329-7.

SALHI, M.; BESSONART, M. Growth, survival and fatty acid composition of Rhamdia quelen (Quoy and Gaimard, 1824) larvae fed on artificial diet alone or in combination with Artemia nauplii. Aquaculture Research, v.44, n.1, p.41-49, 2012. Available from: <http://onlinelibrary.wiley.com/doi/10.1111/ j.1365-2109.2011.03004.x/pdf>. Accessed: Apr. 10, 2013. doi: 10.1111/j.1365-2109.2011.03004.x.

SHIAU, S.Y. Utilization of carbohydrates in warmwater fish - with particular reference to tilapia, Oreochromis niloticus x $\boldsymbol{O}$. aureus. Aquaculture, v.151, n.1-4, p.79-96, 1997. Available from: <http:/ ac.els-cdn.com/S0044848696014913/1-s2.0-S0044848696014913main.pdf? tid=2395f940-a208-11e3-a1fc-00000aab0f6c\&acdnat= 1393764339_5be8dff5cad0cba9c5218ab0e5773781>. Accessed: Aug. 17, 2012. doi: 10.1016/S0044-8486(96)01491-3.

SILVA, T.S.C. et al. Digestibility of feed ingredients for the striped surubim Pseudoplatystoma reticulatum. Aquaculture Nutrition, v.19, n.4, p.491-498, 2013. Available from: <http://onlinelibrary. wiley.com/doi/10.1111/anu.12000/pdf>. Accessed: Sept. 15, 2013. doi: 10.1111/anu.12000.

TEIXEIRA, E.A. et al. Coeficientes de digestibilidade aparente de alimentos energéticos para juvenis de surubim. Revista Brasileira de Zootecnia, v.39, n.6, p.1180-1185, 2010. Available from: $<$ http://www.scielo.br/pdf/rbz/v39n6/03.pdf > . Accessed: Aug. 19, 2012. doi: 10.1590/S1516-35982010000600003. 